\title{
Kinerja Perusahaan Tekstil dan Garment
}

\author{
Darmanto $^{1)}$, Kun Ismawati ${ }^{2)}$ \\ 1,2Program Studi Akuntansi Fakultas Ekonomi Universitas Surakarta \\ *Email korespondensi: antodarma50@gmail.com
}

\begin{abstract}
Bussiness competition in the textile and garment industry is now increasingly high, need to be managed properly, especially it's financial performance. This study aims to determine the effect of capital structure on financial performance on textile and garment companies listed on the Indonesia Stock Exchange in 2016-2018 both partially and simultaneously. Capital structure is measured by Debt to Asset Ratio (DAR) (X1), Debt to Equity Ratio (DER) (X2), and Long term Debt to Equity Ratio (LtDER)(X3). Company performance is measured by Return on Investment $(R O I)(Y)$. This research is a quantitative case study. Secondary data obtained from the annual financial statetments. The population of the research are 21 companies. The number of samples in this study were 8 companies. The analysis technique used is multiple regression to test the effect of independent variables on the dependent variable. The results showed that partially DAR and DER variables significantly influence the ROI, while the LtDER variable has no significant effect on ROI. All three variables have a significant effect on ROI simultaneousl.
\end{abstract}

Keywords: capital structure, financial performance, industry

Saran sitasi: Darmanto., \& Ismawati, K. (2020). Kinerja Perusahaan Tekstil dan Garment. Jurnal Akuntansi dan Pajak, 21 (1), 194-204. doi: http://dx.doi.org/10.29040/jap.v21i1.1110

DOI: http://dx.doi.org/10.29040/jap.v21i1.1110

\section{PENDAHULUAN}

Struktur modal optimal menjadi salah satu hal penting yang harus ditetapkan perusahaan dalam meraih tujuan bisnis. Riyanto (2010: 297) berpendapat struktur modal menjadi ukuran kebijakan perusahaan saat penentuan jenis surat berharga yang diemisi. Fahmi (2015: 184) menyatakan bahwa struktur modal menjadi ilustrasi keuangan perusahaan dan merupakan perbandingan antara modal asing dan modal sendiri bagi pembiayaan kegiatannya.

Perekonomian Indonesia telah mencatat bahwa industri tekstil dan garment merupakan industri unggulan padat karya. World Integrated Trade Solution-Worldbank (WITS-Worldbank) melaporkan bahwa tahun 2019 nilai ekspor industri tekstil dan produk tekstil Indonesia menempati peringkat ke-16 atau sebesar $1,69 \%$ dari pasar ekspor dunia (http://bisnisbandung.com/2019/05/24). Industri ini memang termasuk 10 komoditas ekspor unggulan pada urutan kedua nilai ekspor nonmigas sesudah kelapa sawit, tapi nilai ekspornya mengalami penurunan yang diakibatkan permasalahan efisiensi dan kinerjanya yang kurang memuaskan.
Kinerja perusahaan go public sangat disorot oleh masyarakat luas, sehingga perusahaan tertuntut untuk menampilkan kinerja yang baik, terutama kinerja keuangannya. Dasar pengukuran kinerja perusahaan adalah analisis rasio keuangan, yang salah satunya adalah analisis profitabilitas. Sartono (2010: 122) menyatakan bahwa profitabilitas merupakan kemampuan perusahaan memperoleh laba dari penjualan, total aktiva maupun modal sendiri. Kasmir (2014: 196) berpendapat bahwa rasio profitabilitas merupakan rasio untuk menilai kemampuan perusahaan dalam mencari keuntungan. Profitabilitas dapat diukur dengan Return on Investment (ROI). Syamsuddin (2011: 63) menyatakan bahwa Return on Investment (ROI) merupakan perbandingan antara laba bersih setelah pajak dengan total aktiva, sedangkan Sutrisno (2012: 223) berpendapat bahwa return on investment (ROI) adalah rasio yang menunjukan kemampuan perusahaan untuk mendapatkan keuntungan yang digunakan untuk menutupi investasi yang dikeluarkan.

Beberapa penelitian telah banyak dilakukan tentang kinerja keuangan perusahaan. Penelitian yang 


\section{Jurnal Akuntansi dan Pajak, 21 (01), 2020, 195}

menjelaskan pengaruh positif signifikan antara lain: bahwa secara simultan Debt to Asset Ratio (DAR), Debt to Equity Ratio (DER) dan Long term Debt to Equity Ratio (LtDER) berpengaruh terhadap kinerja perusahaan yang diproksikan dengan Return On Investment (ROI) (Setiana dan Rahayu, 2012; Maulita dan Tania, 2018), dan terhadap nilai perusahaan yang diproksikan dengan PBV (Permatasari dan Azizah, 2018). DAR berpengaruh positif dan signifikan pada kinerja perusahaan yang diproksikan dengan ROI (Nasrun, 2014; Fachry, 2016). DAR berpengaruh positif signifikan pada kinerja perusahaan yang diproksikan dengan Return on Asset (ROA). DER berpengaruh positif signifikan pada ROI (Ningsih, 2013; Sari dan Dwirandra, 2019), DER berpengaruh positif dan signifikan pada ROA dan Return on Equity (Efendi dan Wibowo, 2017). LtDER berpengaruh positif dan signifikan pada ROI (Nasrun, 2014; Fachry, 2016).

Hasil penelitian pada variabel-variabel bebas yang berpengaruh negatif terhadap kinerja perusahaan antara lain: DAR berpengaruh negatif signifikan pada ROI (Setiana dan Rahayu, 2012; Nasrun, 2014). DER berpengaruh negatif signifikan pada ROI (Sari dan Budiasih, 2014; Fachry, 2016) DER berpengaruh negatif tidak signifikan pada PBV (Mutia, et al, 2018). Variabel bebas terkait dengan penelitian ini yang diteliti dengan hasil tidak berpengaruh pada kinerja antara lain: DAR tidak berpengaruh pada ROE (Efendi dan Wibowo, 2017), DAR tidak berpengaruh pada ROI (Maulita dan Tania, 2018), serta DER tidak berpengaruh pada ROI (Setiana dan Rahayu, 2012).

Hasil penelitian berbeda oleh Mispiyanti (2020) dan Putri (2016) yang menyatakan bahwa struktur modal tidak berpengaruh terhadap nilai perusahaan; sedangkan menurut Haryono, Fitriany, dan Fatima (2017: 138) dinyatakan bahwa struktur modal dapat berpengaruh positif pada kinerja perusahaan karena pengaruh pajak, dan pada titik optimal akan berubah berpengaruh negatif karena peningkatan penggunaan utang yang dapat menimbulkan risiko kebankrutan. Struktur modal juga dianggap berpengaruh negatif signifikan berdasarkan hasil penelitian Wardani dan Dewi (2015).

Teori struktur modal meliputi (Hanafi, 2012: 297):

a. Pendekatan tradisional

Struktur modal optimal menjadi perhatian pendekatan ini. Struktur modal dianggap berpengaruh pada nilai perusahaan. Optimalnya nilai perusahaan diraih dengean mengubah struktur modal perusahaan.

b. Pendekatan Modigliani dan Miller (MM)

Dua ekonom di tahun 1960-an memasukkan unsur pajak pada analisis mereka. Mereka menyimpulkan bahwa nilai perusahaan dengan utang akan lebih tinggi daripada perusahaan tanpa utang. Hal ini disebabkan penghematan pajak dari utang.

c. Trade off teory

Gabungan teori Modigliani dan Miller dengan menyertakan biaya kebangkrutan dan biaya keagenan. Hal ini dianggap akan menimbulkan penghematan pajak dari utang dengan biaya kebangkrutan.

d. Model Miller dengan pajak perusahaan dan personal

Model struktur modal tanpa pajak dan dengan pajak yang dikembangkan Modigliani dan Miller. Nilai perusahaan dengan pajak dianggap lebih tinggi dibanding tanpa pajak. Selisihnya didapatkan dengan menghemat pajak melalui bunga. Model struktur modal ini dikembangkan Miller dengan menyertakan pajak personal. Pemegang saham dan utang harus membayar pajak jika mereka mendapatkan dividen (untuk pemegang saham) atau bunga (untuk debitur). Model ini berpedapat bahwa tujuannya adalah untuk meminimalkan beban pajak yang harus dibayar perusahaan baik pajak perusahaan itu sendiri, pajak pemegang saham, dan pajak pemegang hutang.

e. Packing order teory

Perusahaan dengan tingkat keuntungan lebih tinggi akan memiliki tingkat hutang yang lebih rendah. Hal ini disebabkan karena perusahaan tidak memerlukan dana dari luar. Tingkat keuntungan tinggi membuat dana internal perusahaan telah memadai bagi kepentingan investasi.

f. Teori asimetri informasi dan signaling theory

Konsep signaling dan asimetri informasi sangat terkait. Teori asimetri menyatakan bahwa pihak-pihak yang terkait perusahaan tidak memiliki informasi yang sama tentang prospek dan risiko perusahaan. Pihak tertentu dianggap mempunyai informasi yang lebih baik dibanding pihak luar (investor). Hal inilah yang bisa disebut telah muncul asimetri informasi antara 


\section{Jurnal Akuntansi dan Pajak, 21 (01), 2020, 196}

manajer dan investor. Teori signaling menganggap bahwa struktur modal (penggunaan utang) menjadi signal yang disampaikan manajer ke pasar. Perusahaan yang meningkatkan utang dapat dipandang sebagai perusahaan yang punya keyakinan prospek usaha sehingga manajer makin berani mengambil utang lebih besar. Investor diharapkan dapat menangkap signal baik dari perusahaan tersebut, sehingga utang dianggap sebagai tanda/ signal positif.

Nilai perusahaan bisa diukur menggunakan harga saham atau biaya modal yang dikeluarkan perusahaan. Kasmir (201: 156-159) menyatakan bahwa untuk melakukan analisis struktur modal dapat menggunakan rasio solvabilitas, antara lain:

a. Debt to Asset Rasio (DAR)

Rasio ini mengukur seberapa besar jumlah aktiva perusahaan dibiayai dengan utang. Semakin tinggi rasio berarti semakin besar jumlah modal pinjaman yang digunakan untuk investasi pada aktiva guna menghasilkan keuntungan bagi perusahaan. Rumus: Debt to Asset Rasio $=$ Total Debt $/$ Total Asset $\times 100 \%$.

b. Debt to Equity Ratio (DER)

Debt to Equity Ratio untuk mengetahui perimbangan kewajiban perusahaan dengan modal sendiri, juga menunjukkan kemampuan perusahaan dalam memenuhi kewajiban membayar utangnya dengan jaminan modal sendiri. Rumus: Debt to Equity Ratio = Total Debt / Total Equity x 100\%

c. Long term Debt to Equity Ratio (LtDER)

Rasio yang menunjukan hubungan antara jumlah pinjaman jangka panjang yang diberikan kreditur dengan jumlah modal sendiri yang diberikan oleh pemilik perusahaan, juga mengukur besar perbandingan utang jangka panjang dengan modal sendiri atau besar utang jangka panjang yang dijamin oleh perusahaan sendiri. Rumus: Long term Debt to Equity Rasio = Total Long term Debt / Total Equity x 100\%

Munawir (2014:89) berpendapat bahwa Return On Investment (ROI) adalah rasio profitabilitas untuk mengukur kemampuan perusahaan menghasilkan keuntungan dengan keseluruhan dana yang ditanamkan dalam aset yang digunakan untuk operasi. Kemampuan yang dimaksud adalah dalam menghasilkan laba yang terkait tingkat pengembalian investasi. ROI bersifat komprehensif dan sensitif terhadap faktor lain (tidak dapat berdiri sendiri). ROI juga merupakan alat kontrol perusahaan dalam perencanaan, misalnya dalam melakukan ekspansi. Kelemahan ROI hanya memusatkan pada kinerja yang bersifat jangka pendek, yakni dalam menghasilkan laba. Rumus ROI (Kasmir, 2012: 160): Retun On Investment $=$ Net Profit $/$ Total asset $x 100$ $\%$

Penelitian-penelitian sebelumnya menunjukkan masih ada ketidakkonsistenan hasil, sedangkan kinerja keuangan perusahaan masih menjadi sorotan tajam stakeholder dalam kepentingan mereka masingmasing terhadap perusahaan, sehingga perlu diketahui struktur modal yang optimal untuk menampilkan kinerja keuangan perusahaan yang baik. Beberapa hal ini menarik peneliti untuk melakukan penelitian tentang pengaruh struktur modal terhadap kinerja keuangan perusahaan pada perusahaan tekstil dan garment yang terdaftar di Bursa efek Indonesia (BEI) tahun 2016-2018. Variabel pengukuran yang digunakan adalah Debt to Asset Ratio (DAR), Debt to Equity Ratio (DER) dan Long term Debt to Equity Ratio (LtDER), serta Return On Investment (ROI) perusahaan tekstil dan garment.

Berikut adalah delapan nama perusahaan tekstil dan garment yang menjadi sampel dalam penelitian ini.

Tabel

Sampel Nama Perusahaan Tekstil dan Garment yang Terdaftar di BEI Tahun 2016-2018

\begin{tabular}{|c|l|}
\hline No & \multicolumn{1}{|c|}{ Nama Perusahaan } \\
\hline 1 & Sri Rejeki Isman Tbk \\
\hline 2 & Eratex Djaya Tbk \\
\hline 3 & Polychem Indonesia Tbk \\
\hline 4 & Indo Rama Synthetic Tbk \\
\hline 5 & Pan Brothers Tbk \\
\hline 6 & Star Petrochem Tbk \\
\hline 7 & Trisula Internasional Tbk \\
\hline 8 & Nusantara Inti Corpora Tbk \\
\hline
\end{tabular}

Sumber : www.idx.co.id

Tingkat rata-rata perolehan struktur modal Debt to Asset Ratio, Debt to Equity Ratio, Long Term Debt to equity Ratio dan pengukuran kinerja perusahaan menggunakan nilai Return On Investment (ROI) dengan pengambilan 8 sampel dari 21 perusahaan tekstil dan garment yang terdaftar di BEI tahun 20162018 sebagai berikut: 
Tabel

Tingkat rata-rata perolehan DAR, DER, LtDER dan ROI Perusahaan Tekstil dan Garment yang terdaftar di BEI 2016-2018

\begin{tabular}{|c|c|c|c|c|c|}
\hline No & Tahun & $\begin{array}{c}\text { DAR } \\
\left(X^{\bar{\top}}\right)\end{array}$ & $\begin{array}{c}\text { DER } \\
\left(X^{\bar{\top}}\right)\end{array}$ & $\begin{array}{c}\text { LtDER } \\
\left(X^{\bar{\top}}\right.\end{array}$ & $\begin{array}{c}\text { ROI } \\
\left(X^{-}\right)\end{array}$ \\
\hline 1 & 2016 & 48,47 & 123,93 & 53,41 & 1,18 \\
\hline 2 & 2017 & 46,88 & 132,60 & 50,94 & 0,57 \\
\hline 3 & 2018 & 47,01 & 105,48 & 43,30 & 3,13 \\
\hline
\end{tabular}

Sumber : www.idx.co.id (data diolah kembali)

Tabel diatas menunjukkan bahwa nilai Return On Investment setiap tahun tidak berbanding lurus dengan struktur modalnya yaitu Debt to Asset Ratio (DAR), Debt to Equity Ratio (DER), dan Long term Debt to Equity Ratio (LtDER). Nilai DAR, DER, dan LtDER memiliki tingkat rata-rata lebih besar dibanding dengan tingkat rata-rata dari Return On Investment. Hal tersebut semakin mendukung pentingnya dilakukan penelitian ini.

Permasalahan dalam penelitian ini dirumuskan: (1) apakah Debt to Asset Ratio (DAR) berpengaruh signifikan terhadap kinerja perusahaan tekstil dan garment yang terdaftar di BEI tahun 2016-2018, (2) apakah Debt to Equity Ratio (DER) berpengaruh terhadap kinerja perusahaan tekstil dan garment yang terdaftar di BEI tahun 2016-2018, (3) apakah Long term Debt to Equity (LtDER) berpengaruh terhadap kinerja perusahaan/ tekstil dan garment yang terdaftar di BEI tahun 2016-2018, (4) apakah Debt to Asset Ratio (DAR), Debt to Equity Ratio (DER), dan Long term Debt to Equity (LtDER) berpengaruh secara simultan terhadap kinerja tekstil dan garment yang terdaftar di BEI tahun 2016-2018.

Hipotesis yang diajukan dalam penelitian ini yakni:

a. H:1: Debt to Asset Ratio (DAR) berpengaruh signifikan terhadap kinerja perusahaan tekstil dan garment yang terdaftar di BEI tahun 2016-2018.

b. H:2: Debt to Equity Ratio (DER) berpengaruh signifikan terhadap kinerja perusahaan tekstil dan garment yang terdaftar di BEI tahun 2016-2018.

c. H:3: Long term Debt to Equity (LtDER) berpengaruh signifikan terhadap kinerja perusahaan tekstil dan garment yang terdaftar di BEI tahun 2016-2018.

d. H:4: Debt to asset Ratio, Debt to Equity Ratio, Long term Debt to Equity Ratio berpengaruh secara simultan terhadap kinerja perusahaan tekstil dan garment yang terdaftar di BEI tahun 2016-2018.

\section{METODE PENELITIAN}

\section{Populasi}

Populasi penelitian ini meliputi perusahaan tekstil dan garment yang terdaftar di BEI dalam periode tahun 2016-2018. Sampel diambil menggunakan metode purposive sampling dengan kriteria:

a. Perusahaan yang telah menerbitkan laporan keuangan dari tahun 2016 sampai 2018 dengan lengkap.

b. Perusahaan memiliki data yang dibutuhkan untuk pengukuran variabel penelitian.

Sampel yang diperoleh adalah 8 perusahaan. Daftar perusahaan yang menjadi sampel penelitian adalah sebagai berikut:

\section{Tabel}

Daftar Perusahaan Tekstil dan Garment yang menjadi Sampel Penelitian

\begin{tabular}{|c|c|l|}
\hline No & $\begin{array}{c}\text { Kode } \\
\text { Perusahaan }\end{array}$ & \multicolumn{1}{|c|}{ Nama Perusahaan } \\
\hline 1 & ADMG & Polychem Indonesia Tbk \\
\hline 2 & ERTX & Eratex Djaya Tbk \\
\hline 3 & SRIL & Sri Rejeki Isman Tbk \\
\hline 4 & INDR & Indo Rama Synthetic Tbk \\
\hline 5 & PBRX & Pan Brothers Tbk \\
\hline 6 & STAR & Star Petrochem Tbk \\
\hline 7 & TRIS & Trisula Internasional Tbk \\
\hline 8 & UNIT & Nusantara Inti CorporaTbk \\
\hline
\end{tabular}

Sumber: $\underline{w w w . i d x . c o . i d}$

\section{Definisi Operasional Variabel}

Variabel independen/ variabel bebasnya adalah struktur modal. Kasmir (2012: 151) berpendapat bahwa rasio solvabilitas atau leverage merupakan rasio yang digunakan untuk mengukur sejauh mana aktiva perusahaan dibiayai oleh hutang. Rasio-rasio solvabilitas berikut ini yang digunakan untuk menganalisis struktur modal:

a. Debt to Asset Ratio (DAR)

Rasio ini digunakan untuk mengukur seberapa besar aktiva perusahaan dibiayai 
Jurnal Akuntansi dan Pajak, 21 (01), 2020, 198

dengan utang. Rasio yang semakin tinggi menunjukkan semakin besarnya jumlah modal pinjaman yang digunakan untuk investasi pada aktiva untuk menghasilkan keuntungan. Rumus: Debt to Asset Ratio $=$ Total Debt $/$ Total Asset $x$ $100 \%$

b. Debt to Equity Ratio (DER)

Rasio ini untuk mengukur perimbangan antara kewajiban perusahaan dengan modal sendiri. DER juga digunakan untuk mengetahui kemampuan perusahaan memenuhi kewajiban membayar utang dengan jaminan modal sendiri. Rumus:

Debt to Equity Ratio = Total debt $/$ Total equity $\times 100 \%$

c. Long term Debt to Equity Ratio (LtDER)

Rasio yang menunjukkan hubungan jumlah pinjaman jangka panjang yang diberikan kreditur dengan jumlah modal sendiri yang diberikan pemilik perusahaan. Rasio ini juga digunakan mengukur seberapa besar perbandingan utang jangka panjang yang dijamin oleh modal sendiri. Rumus:

Long term Debt to Equity Ratio = Total long term debt / Total equity $\times 100 \%$

Variabel independen/ bebas:

$\mathrm{X}$ : Struktur Modal

$\mathrm{X} 1$ : Debt to Asset Ratio (DAR)

$\mathrm{X} 2$ : Debt to Equity Ratio (DER)

X3: Long term Debt to Equity Ratio (LtDER)

Variabel dependen (terikat) dari penelitian ini adalah kinerja perusahaan. Pengukuran kinerja perusahaan menggunakan analisis Return On Investment (ROI). Munawir (2014: 89) berpendapat bahwa Return On Investment adalah salah satu bentuk rasio profitabilitas untuk dapat mengukur kemampuan perusahaan menghasilkan keuntungan dengan keseluruhan dana yang ditanamkan dalam aset yang digunakan untuk operasional, sekaligus mengukur tingkat pengembalian investasi. Rumus: Retun On Investment $=$ Net Profit/ Total asset $x 100$ $\%$.

\section{Teknik Pengumpulan Data}

Metode pengumpulan data yang digunakan adalah metode pengumpulan data dari basis data yang merupakan pencatatan data laporan tahunan pada perusahaan tekstil dan garment yang terdaftar di BEI untuk mengetahui rasio-rasio keuangannya selama periode tahun 2016-2018. Data dalam penelitian ini diperoleh melalui media internet dari laman www.idx.co.id .

\section{Pengujian Data}

Data diuji menggunakan deskripsi statistik dari masing-masing variabel seperti: mean, standar deviasi, nilai maksimum, dan nilai minimum.

\section{Teknik Analisis Data}

\section{a. Pengujian Asumsi Klasik}

1) Uji Normalitas: Penelitian ini menggunakan analisis grafik dengan metode Normal Probability Plot pada SPSS. Metode ini membandingkan distribusi kumulatif data sesungguhnya dengan distribusi kumulatif dari distribusi normal.

2) Uji Multikolinieritas: dengan melihat angka Tolerance Value dan Variance Inflation Factor (VIF) $>10$ atau tolerance $<0,10$ maka terjadi gejala multikolinieritas.

3) Uji Autokorelasi: menggunakan uji Durbin Watson (DW) yang digunakan dengan membandingkan nilai Durbin Watson dengan tabel Durbin Watson yang memuat nilai batas atas (upper bound atau $\mathrm{d}_{\mathrm{U}}$ ) dan nilai batas bawah (lower bound atau $\mathrm{d}_{\mathrm{L}}$ ).

\section{b. Teknik Analisis Data}

Sugiyono (2014: 277) menyatakan bahwa analisis regresi linier berganda bermaksud meramalkan bagaimana keadaan (naik turunnya) variabel dependen (kriterium) bila dua atau lebih variabel independen sebagai faktor prediator dimanipulasi (dinaik turunkan nilainya)Model regresi berganda digunakan dalam penelitian ini untuk menjelaskan kekuatan dan arah pengaruh beberapa variabel bebas atau variabel penjelas (independent/ explanatory variable) terhadap satu variabel terikat (dependent variable). Analisis ini meramalkan bagaimana keadaan (naik turunnya) variabel dependen (kriterium) bila dua atau lebih variabel independen sebagai faktor prediktor dimanipulasi (dinaikturunkan nilainya). Teknik analisis data dalam penelitian ini menggunakan model regresi berganda yang akan diolah dengan program komputer SPSS. Persamaan regresi linier berganda sebagai berikut:

$$
\mathrm{Y}=a+b_{1} \mathrm{x}_{1}+b_{2} \mathrm{X}_{2}+b_{3} \mathrm{X}_{3}+\mathrm{e}
$$


Jurnal Akuntansi dan Pajak, 21 (01), 2020, 199

Keterangan:

$\mathrm{Y}=$ Kinerja Perusahaan (Return on Investment)

$a \quad$ Konstanta

$b \quad=$ Koefisien Regresi

$\mathrm{X}_{1}=$ Debt to Assets Ratio

$\mathrm{X}_{2}=$ Debt to Equity Ratio

$\mathrm{X}_{3}=$ Long term Debt to Equity Ratio

$\mathrm{e} \quad=$ Error

\section{c. Pengujian Hipotesis}

1) Uji T-statistik: menguji koefisien regresi secara parsial dari variabel independen (mengetahui apakah masing-masing variabel independen secara signifikan berpengaruh terhadap variabel dependen). Jika koefisien signifikan $\mathrm{t}(\beta \mathrm{i})<$ taraf signifikansi yang telah ditetapkan $(\alpha=5 \%)$, maka secara parsial variabel independen tersebut berpengaruh signifikan terhadap variabel dependen, sehingga $\mathrm{H}_{0}$ ditolak.

2) Uji F-statistik: menguji pengaruh seluruh variabel independen secara bersamabersama atau simultan terhadap variabel dependen. Program SPSS, uji Anova atau F test digunakan bila didapatkan koefisien signifikan $\mathrm{t}(\beta \mathrm{i})<$ taraf signifikansi yang telah ditetapkan $(\alpha=5 \%)$, maka model regresi bisa dipakai untuk memprediksi variabel dependen.

3) Koefisien Determinasi $\left(\mathbf{R}^{2}\right)$ : untuk mengetahui besarnya pengaruh variabel independen yaitu DAR, DER, dan LtDER terhadap variabel dependen yaitu $R O I$. Nilai $\mathrm{R}^{2}$ mempunyai interval antara angka 0 sampai $1\left(0 \leq \mathrm{R}^{2} \leq 1\right)$. Koefisien determinasi yang semakin mendekati nol berarti semakin kecil pula pengaruh semua variabel independen terhadap variabel dependen, dan sebaliknya jika koefisien determinasi mendekati angka satu, semakin besar pula pengaruh semua variabel independen terhadap variabel dependen.

\section{HASIL DAN PEMBAHASAN}

\section{Hasil Statistik Deskriptif}

Hasil uji statistik deskriptif terhadap seluruh variabel bebas dan variabel terikat ditunjukkan dalam tabel berikut:
Tabel

Statistik Deskriptif DAR, DER, LtDER, dan ROI pada Perusahaan Tekstil dan Garment yang Terdaftar di BEI Tahun 2016-2018 Descriptive Statistics

\begin{tabular}{|l|c|r|r|r|r|}
\hline & $\mathrm{N}$ & Min & Max & \multicolumn{1}{c|}{ Mean } & $\begin{array}{c}\text { Std. } \\
\text { Deviation }\end{array}$ \\
\hline DAR & 24 & 13,09 & 69,83 & 47,4554 & 18,35457 \\
\hline DER & 24 & 15,07 & 389,26 & 120,6804 & 90,44512 \\
\hline LtDER & 24 & 0,57 & 153,81 & 49,1871 & 52,07715 \\
\hline ROI & 24 & $-6,80$ & 9,97 & 1,6254 & 3,55468 \\
\hline $\begin{array}{l}\text { Valid N } \\
\text { (listwise) }\end{array}$ & 24 & & & & \\
\hline
\end{tabular}

Sumber: diolah dengan SPSS 25

Penjelasan mengenai statistik deskripsi untuk masing-masing variabel adalah sebagai berikut:

a. Jumlah pengamatan untuk variabel Debt to Asset Ratio adalah 24 yang diperoleh dari 8 perusahaan dengan periode 3 tahun. Memiliki nilai minimum 13,09, nilai maksimum 69,83, nilai rata-rata sebesar 47,4554dan standar deviasi 18,35457 .

b. Jumlah pengamatan untuk variabel Debt to Equity Ratio adalah 24 yang diperoleh dari 8 perusahaan dengan periode 3 tahun. Memiliki nilai minimum 15,07 , nilai maksimum 389,26 , nilai rata-rata sebesar 120,680 dan standar deviasi 90,44512.

c. Jumlah pengamatan untuk variabel Long term Debt to Equity Ratio adalah 24 yang diperoleh dari 8 perusahaan dengan periode 3 tahun. Memiliki nilai minimum 0,57 , nilai maksimum 153,81, nilai rata-rata sebesar 49,1871 dan standar deviasi 52,07715.

d. Jumlah pengamatan untuk variabel Return On Investement adalah 24 yang diperoleh dari 8 perusahaan dengan periode 3 tahun. Memiliki nilai minimum $-6,80$, nilai maksimum 9,97 , nilai rata-rata sebesar 1,6254 dan standar deviasi 3,55468 .

\section{Uji Asumsi Klasik}

Uji normalitas bertujuan mengetahui apakah variabel bebas dan variabel terikatnya memiliki distribusi normal atau tidak. Hasil uji normalitas secara grafik probability plot variabel ROI ditunjukkan pada gambar 4.1 dengan menggunakan bantuan SPSS versi 25. 


\section{Gambar Normal P-P Plot}

Hasil Uji Normalitas pada Perusahaan Tekstil dan Garment yang Terdaftar di BEI Tahun 2016-2018

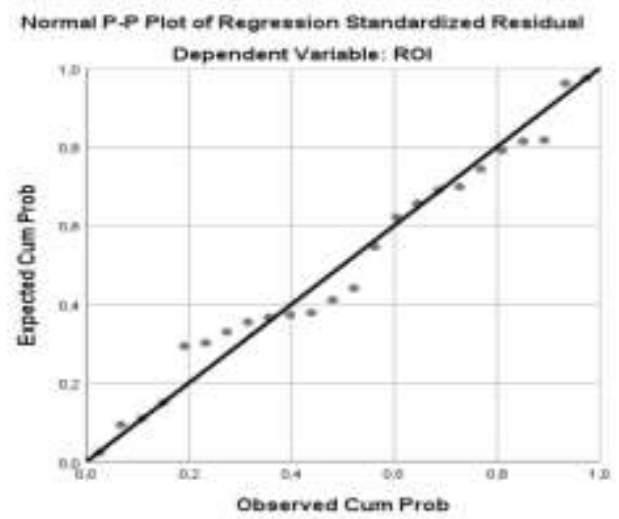

Sumber: diolah dengan SPSS 25

Gambar menunjukkan bahwa grafik normal probability plot of regresison standardized memiliki pola grafik normal. Hal ini terlihat dari titik-titik menyebar disekitar garis diagonal dan penyebarannya mengikuti garis diagonal. Kesimpulan menyatakan bahwa model regresi layak dipakai karena memenuhi asumsi normalitas.

Uji multikolinearitas bertujuan untuk mengetahui apakah variabel-variabel yang digunakan mempunyai lebih dari satu hubungan linear (pengaruh). Uji multikolinearitas dilakukan dengan menggunakan uji nilai tolerance value atau Variance Inflation Factor (VIF). Batas tolerance value adalah 0.01 dan VIF adalah 10. Apabila tolerance value kurang dari 0.01 atau nilai VIF lebih besar dari 10 maka terjadi multikolinearitas. Hasil uji multikolinearitas disajikan dalam tabel sebagai berikut:

\section{Tabel}

Hasil Uji Multikolinearitas pada Perusahaan

Tekstil dan Garment yang Terdaftar di BEI

\section{Tahun 2016-2018}

Coefficients $^{a}$

\begin{tabular}{|c|c|c|c|}
\hline \multirow{2}{*}{\multicolumn{2}{|c|}{ Model }} & \multicolumn{2}{|c|}{ Collinearity Statistics } \\
\hline & & \multirow{2}{*}{ Tolerance } & \multirow[t]{2}{*}{ VIF } \\
\hline 1 & $($ Constant $)$ & & \\
\hline & DAR & 0,215 & 4,657 \\
\hline & DER & 0,274 & 3,645 \\
\hline & LtDER & 0,383 & 2,608 \\
\hline
\end{tabular}

a. Dependent Variable: ROI

Sumber: diolah dengan SPSS 25

Hasil uji multikolinieritas menunjukkan bahwa nilai tolerance dari ketiga variabel independen lebih besar daripada 0.10 dan VIF lebih kecil daripada 10 .
Kesimpulan diperoleh bahwa dalam model regresi tersebut tidak terdapat masalah multikolinieritas, maka model regresi yang ada layak untuk dipakai.

Uji autokorelasi bertujuan untuk menguji apakah dalam suatu model regresi linier berganda terdapat korelasi antara residual pada periode $\mathrm{t}$ dengan residual periode t-1 (sebelumnya). Pengujian ini dilakukan dengan menggunakan uji Durbin-Watson (DW-test) dengan hasil sebagai berikut:

\section{Tabel}

Hasil Uji Autokolerasi pada Perusahaan Tekstil dan Garment yang Terdaftar di BEI Tahun 20162018

\section{Model Summary ${ }^{b}$}

\begin{tabular}{|l|c|r|r|r|r||}
\hline Model & $\mathrm{R}$ & $\begin{array}{c}R \\
\text { Square }\end{array}$ & $\begin{array}{c}\text { Adjusted } \\
R \text { Square }\end{array}$ & $\begin{array}{c}\text { Std. Error } \\
\text { of the } \\
\text { Estimate }\end{array}$ & $\begin{array}{r}\text { Durbin- } \\
\text { Watson }\end{array}$ \\
\hline 1 & $0,686^{\mathrm{a}}$ & 0,471 & 0,391 & 2,77292 & 1,840 \\
\hline
\end{tabular}

a. Predictors: (Constant), LtDER, DER, DAR

b. Dependent Variable: ROI

Sumber: diolah dengan SPSS 25

Output diatas menghasilkan nilai DW adalah 1,840, dengan membandingkan nilai DW dengan nilai tabel signifikasi 5\% dan jumlah sampel $\mathrm{N}=24$ serta jumlah variabel independen $3(\mathrm{~K}=3)$ maka, diperoleh nilai $\mathrm{dL}$ (nilai batas bawah) sebesar 1,101 dan dU (nilai batas atas) sebesar 1,656. Nilai DW lebih tinggi dari nilai batas atas yakni 1,840 sehingga dapat disimpulkan bahwa dalam uji ini tidak terdapat autokorelasi.

\section{Pengujian Hipotesis}

Pengaruh Debt to Asset Ratio (DAR), Debt to Equtiy Ratio (DER), Long term Debt to Equity Ratio (LtDER) secara parsial terhadap kinerja perusahaan Return On Investmen $t(\mathrm{ROI})$ dapat diketahui dari hasil uji t yang terdapat pada tabel berikut:

\section{Tabel}

Hasil Uji T-statistik Perusahaan Tekstil dan Garment yang Terdaftar di BEI Tahun 2016-2018

\section{Coefficients $^{a}$}

\begin{tabular}{|c|c|c|c|c|c|}
\hline \multirow{2}{*}{ Model } & \multicolumn{2}{|c|}{$\begin{array}{l}\text { Unstandardize } \\
d \text { Coefficients }\end{array}$} & \multirow{2}{*}{$\begin{array}{c}\text { Standardized } \\
\text { Coefficients } \\
\text { Beta }\end{array}$} & \multirow[t]{2}{*}{$\mathrm{t}$} & \multirow[t]{2}{*}{ Sig. } \\
\hline & B & $\begin{array}{c}\text { Std. } \\
\text { Error }\end{array}$ & & & \\
\hline \begin{tabular}{|l} 
(Constant) \\
\end{tabular} & $-4,257$ & 2,050 & & $-2,077$ & 0,051 \\
\hline DAR & 0,183 & 0,068 & 0,947 & 2,697 & 0,01 \\
\hline DER & $-0,033$ & 0,012 & $-0,838$ & $-2,699$ & 0,014 \\
\hline LtDER & 024 & 0,018 & 0,344 & 1.311 & 0,2 \\
\hline
\end{tabular}

a. Dependent Variable: ROI

Sumber: diolah dengan SPSS 25 
Output SPSS menunjukkan bahwa secara individu variabel Debt to Asset Ratio (DAR) memberikan nilai koefisien 0,183 dengan probabilitas signifikansi 0,014 (<0,05). Variabel Debt to Equtiy Ratio (DER) memberikan nilai koefisien -0,033 dengan probabilitas signifikansi $0,014 \quad(<0,05)$. Variabel Long term Debt to Equity Ratio (LtDER) memberikan nilai koefisien 0,024 dengan probabilitas signifikansi 0,205 (>0,05). Temuan ini menunjukkan bahwa variabel Debt to Asset Ratio (DAR) dan Debt to Equtiy Ratio (DER) secara parsial berpengaruh signifikan terhadap kinerja perusahaan yang diukur dengan Return On Investment (ROI). Long term Debt to Equity Ratio(LtDER) secara parsial tidak berpengaruh signifikan terhadap kinerja perusahaan yang diukur dengan Return On Investment (ROI).

Uji F digunakan untuk menguji apakah variabelvariabel independen secara bersama-sama berpengaruh signifikan terhadap variabel dependen. Langkah-langkah Uji F sebagai berikut:

a. Menentukan Hipotesis

Ho : $\beta=0$, artinya variabel independen secara bersama-sama tidak berpengaruh signifikan terhadap variabel dependen.

Ha : $\beta \neq 0$, artinya variabel independen secara bersama-sama berpengaruh signifikan terhadap variabel dependen.

b. Menentukan Tingkat Signifikan

Tingkat signifikan pada penelitian ini adalah 5\% artinya risiko kesalahan mengambil keputusan $5 \%$.

c. Pengambilan Keputusan

1) Jika probabilitas (sig F) $<\alpha(0,05)$ atau $F$ hitung $>\mathrm{F}$ tabel maka, Ho ditolak, artinya ada pengaruh yang signifikan dari variabel independen terhadap variabel dependen.

2) Jika probabilitas (sig F) $>\alpha(0,05)$ atau $F$ hitung $<\mathrm{F}$ tabel maka, Ho diterima, artinya tidak ada pengaruh yang signifikan dari variabel independen terhadap variabel dependen.

Pengujian pengaruh Debt to Asset Ratio (DAR), Debt to Equity Ratio (DER), dan Long term Debt to Equity Ratio (LtDER) secara simultan terhadap kinerja perusahaan (ROI) dilakukan melalui uji statistik f. Hasil uji tersebut terdapat pada tabel berikut:
Tabel

Hasil Uji F-statistik Perusahaan Tekstil dan Garment yang Terdaftar di BEI Tahun 2016-2018 ANOVA $^{\mathrm{a}}$

\begin{tabular}{|c|c|c|c|c|c|c|}
\hline \multicolumn{2}{|c|}{ Model } & $\begin{array}{c}\text { Sum of } \\
\text { Squares }\end{array}$ & df & $\begin{array}{c}\text { Mean } \\
\text { Square }\end{array}$ & $\mathrm{F}$ & Sig. \\
\hline \multirow[t]{3}{*}{1} & Regression & 136,840 & 3 & 45,613 & 5,932 & $0,005^{\mathrm{b}}$ \\
\hline & Residual & 153,782 & 20 & 7,689 & & \\
\hline & Total & 290,622 & 23 & & & \\
\hline
\end{tabular}

a. Dependent Variable: ROI

b. Predictors: (Constant), LtDER, DER, DAR Sumber: diolah dengan SPSS 25

Berdasarkan tabel diatas diketahui nilai $\mathrm{F}$ hitung 5,932 dan signifikansi 0,005. Hasil ini menunjukkan bahwa variabel Debt to Asset Ratio, Debt to Equity Ratio, dan Long term Debt to Equity Ratiosecara simultan berpengaruh signifikan terhadap kinerja perusahaan yang diukur dengan Return On Investment.

Kekuatan pengaruh variabel bebas terhadap variasi variabel terikat dapat diketahui dari besaran nilai koefisien determinan $\left(\mathrm{R}^{2}\right)$, yang berada antara nol dan satu.

Tabel

Hasil Koefisien Determinasi $\left(\mathbf{R}^{2}\right)$ Perusahaan

Tekstil dan Garment yang Terdaftar Di BEI

Tahun 2016-2018

Model Summary ${ }^{b}$

\begin{tabular}{|l|r|r|r|r||}
\hline Model & $\mathrm{R}$ & $\begin{array}{c}R \\
\text { Square }\end{array}$ & $\begin{array}{c}\text { Adjusted } R \\
\text { Square }\end{array}$ & $\begin{array}{l}\text { Std. Error of } \\
\text { the Estimate }\end{array}$ \\
\hline 1 & $0,686^{\mathrm{a}}$ & 0,471 & 0,391 & 2,77292 \\
\hline
\end{tabular}

a. Predictors: (Constant), LtDER, DAR, DER

b. Dependent Variable: ROI

Sumber: diolah dengan SPSS 25

Tabel diatas diketahui nilai koefisien determinasi (R Square) sebesar 0,471 atau sama dengan $47,1 \%$ dan angka koefisien korelasi (R) adalah 0,686 atau $68,6 \%$. Angka tersebut menunjukkan bahwa koefisien korelasi (R) yang terjadi antaraDebt to Asset Ratio (DAR), Debt to Equity Ratio (DER), Long term Debt to Equity Ratio (LtDER) dengan Return On Investment(ROI) berpengaruh sebesar $47,1 \%$ sedangkan sisanya $(100 \%-47,1 \%=52,9 \%)$ dipengaruhi oleh variabel lain yang tidak dimasukkan dalam model regresi penelitian ini. Hasil diatas menunjukkan hubungan yang signifikan yang terlihat 
dari nilai $\mathrm{R}$ sebesar 0,686 atau $68,8 \%$, angka ini lebih besar dari nilai $50 \%$.

Persamaan regresi dapat dilihat dari tabel hasil uji coefficients hasil output SPSS versi 25 terhadap ketiga variabel independen terhadap kinerja perusahaan (ROI) yang ditunjukkan pada tabel berikut:

\section{Tabel}

Hasil Uji Regresi Liniear Berganda Pada Perusahaan Tekstil dan Garment yang Terdaftar di BEI 2016-2018

Coefficients $^{a}$

\begin{tabular}{|c|c|c|c|c|c|c|}
\hline \multirow{2}{*}{\multicolumn{2}{|c|}{ Model }} & \multicolumn{2}{|c|}{$\begin{array}{l}\text { Unstandardize } \\
d \text { Coefficients }\end{array}$} & \multirow{2}{*}{$\begin{array}{c}\text { Standardized } \\
\text { Coefficients } \\
\text { Beta }\end{array}$} & \multirow[t]{2}{*}{$\mathrm{t}$} & \multirow[t]{2}{*}{ Sig. } \\
\hline & & B & $\begin{array}{l}\text { Std. } \\
\text { Error }\end{array}$ & & & \\
\hline \multirow[t]{4}{*}{$\begin{array}{lll}1 & & \\
\end{array}$} & (Constant) & $-4,257$ & 2,050 & & $-2,077$ & 0,05 \\
\hline & DAR & 0,183 & 0,068 & 0,947 & 2,697 & 0,01 \\
\hline & DER & $\mid$\begin{tabular}{|l|}
$-0,033$ \\
\end{tabular} & 0,012 & $-0,838$ & $-2,699$ & 0,01 \\
\hline & LtDER & 0,024 & 0,018 & 0,344 & 1,311 & 0,20 \\
\hline
\end{tabular}

a. Dependent Variable: ROI

Sumber: diolah dengan SPSS 25

Analisis regresi linear berganda digunakan untuk menguji pengaruh dua atau lebih variabel independen terhadap satu variabel dependen. Persamaan regresi dapat dilihat dari tabel diatas. Pada tabel tersebut yang dibaca adalah nilai dalam kolom $\mathrm{B}$, baris pertama menunjukkan konstanta (a) dan baris selanjutnya menunjukkan koefisien variabel independen. Berdasarkan tabel diatas model regresi yang digunakan adalah sebagai berikut:

$\mathrm{ROI}=(-4,257)+0,183 \mathrm{DAR}-0,033 \mathrm{DER}+0,024$

\section{LtDER}

Nilai kostanta dengan koefisien regresi pada tabel 4.12 dapat dijelaskan sebagai berikut:

a. Konstata sebesar $-4,257$ artinya, jika $\mathrm{X}_{1}, \mathrm{X}_{2}, \mathrm{X}_{3}$ nilainya 0 maka, nilai ROI nya adalah 4,257 .

b. Koefisien regresi variabel $\mathrm{X}_{1}$ (DAR) sebesar 0,183 artinya jika $\mathrm{X}_{1}$ dinaikan1\%, maka nilai ROI akan mengalami peningkatan sebesar 0,183 dengan asumsi bahwa variabel independen lain nilainya tetap.

c. Koefisien regresi variabel $\mathrm{X}_{2}$ (DER) sebesar 0,033 artinya jika $\mathrm{X}_{2}$ dinaikan1\%, maka nilai ROI akan mengalami penurunan sebesar 0,033 dengan asumsi bahwa variabel independen lain nilainya tetap. d. Koefisien regresi variabel $\mathrm{X}_{3}$ (LtDER) sebesar 0,024 artinya jika $\mathrm{X}_{1}$ dinaikan $1 \%$, maka nilai ROI akan mengalami peningkatan sebesar 0,024 dengan asumsi bahwa variabel independen lain nilainya tetap.

\section{Pembahasan}

Penelitian ini melakukan pengujian antara pengaruh struktur modal yang diukur menggunakan Debt to Asset Ratio (DAR), Debt to Equity Ratio (DER), dan Long term Debt to Equity Ratio (LtDER) terhadap kinerja perusahaan yang diukur menggunakan Return On Investment (ROI) pada perusahaan tekstil dan garment yang terdaftar di BEI tahun 2016-2018.

\section{a. Pengaruh Debt to Asset Ratio (DAR) terhadap kinerja perusahaan (ROI)}

Rasio ini digunakan untuk mengukur seberapa besar jumlah aktiva perusahaan dibiayai dengan utang. Semakin tinggi rasio ini berarti semakin besar jumlah modal pinjaman yang digunakan untuk investasi pada aktiva guna menghasilkan keuntungan bagi perusahaan. Temuan penelitian menunjukan bahwa Debt to Asset Ratio (DAR) berpengaruh signifikan terhadap kinerja perusahaan (ROI). Hal ini dapat dilihat dari hasil Uji-t yang menunjukan angka yang lebih kecil dari taraf signinifkan yang telah ditetapkan. Penelitian sebelumnya yang dilakukan oleh Setiana dan Rahayu (2012), Ningsih (2013), Nasrun (2014), dan Fachry (2016) menunjukan hasil yang sama yaitu Debt to Asset Ratio berpengaruh signifikan terhadap kinerja perusahaan. Berbeda dengan penelitian yang dilakukan oleh Dian dan Tania (2018) yang menunjukan bahwa Debt to Asset Ratio tidak berpengaruh signifikan terhadap kinerja perusahaan (ROI).

\section{b. Pengaruh Debt to Equity Ratio (DER) terhadap kinerja perusahaan (ROI)}

Debt to Equity Ratio (DER) merupakan rasio yang digunakan untuk mengukur perimbangan antara kewajiban yang dimiliki perusahaan dengan modal sendiri. Rasio ini juga dapat berarti sebagai kemampuan perusahaan dalam memenuhi kewajiban membayar hutangnya dengan jaminan modal sendiri. Temuan penelitian menunjukkan bahwa Debt to Equity Ratio (DER) berpengaruh secara signifikan terhadap kinerja perusahaan (ROI). Hal ini dapat dilihat dari hasil Uji t-statistik bahwa nilai t untuk variabel Debt to Equity Ratio (DER) lebih kecil dari taraf signifikan yang telah ditetapkan. Berbeda 
dengan hasil penelitian penulis sebelumnya yang menemukan bahwa Debt to Equity Ratio (DER) tidak berpengaruh signifikan pada kinerja perusahaan yang diproksikan dengan Return on Equity (Ismawati, 2019: 549).

\section{c. Pengaruh Long term Debt to Equity Ratio} (LtDER) terhadap kinerja perusahaan (ROI)

Rasio ini menunjukkan hubungan antara jumlah pinjaman jangka panjang yang diberikan kreditur dengan jumlah modal sendiri yang diberikan oleh pemilik perusahaan. Rasio ini juga digunakan untuk mengukur seberapa besar perbandingan antara utang jangka panjang dengan modal sendiri atau seberapa besar utang jangka panjang dijamin oleh modal sendiri (Kasmir, 2012:159). Temuan penelitian menunjukkan bahwa Long term Debt to Equity Ratio (LtDER) tidak berpengaruh secara signifikan terhadap kinerja perusahaan.Penelitian sebelumnya yang dilakukan oleh Fachry (2016) menunjukkan hasil yang sama yakni Long term Debt to Equity Ratio (LtDER) tidak berpengaruh signifikan terhadap kinerja keuangan (ROI). Penelitian yang dilakukan oleh Nasrun (2014) dan Dian dan Tania (2018) menunjukan hasil bahwa Long term Debt to equity Ratio (LtDER) berpengaruh signifikan terhadap kinerja keuangan (ROI).

d. Pengaruh simultan Debt to Asset Ratio, Debt to Equity Ratio, dan Long term Debt to Equity Ratio dengan kinerja keuangan (ROI)

Hasil penelitian yang telah diuraikan, secara simultan dapat diketahui bahwa Debt to Asset Ratio, Debt to Equity Ratio, dan Long term Debt to Equity Ratio berpengaruh signifikan terhadap kinerja keuangan (ROI). Struktur modal berpengaruh signifikan secara simultan terhadap kinerja pada perusahaan tekstil dan garment yang terdaftar di Bursa Efek Indonesia.

\section{KESIMPULAN}

Hasil uji hipotesis membuktikan bahwa Debt to Asset Ratio (DAR) terbukti berpengaruh terhadap kinerja perusahaan. Debt to Equity Ratio (DER) terbukti berpengaruh terhadap kinerja perusahaan. Long term Debt to Equity Ratio (LtDER) tidak terbukti berpengaruh terhadap kinerja perusahaan. Seluruh variabel secara simultan terbukti berpengaruh signifikan terhadap kinerja perusahaan.

Penelitian ini memiliki keterbatasan antara lain pada jenis variabel bebas yang hanya meliputi 3 (tiga) variabel, sehingga dapat menjadi pertimbangan bagi penelitian berikutnya untuk menambahkan variabel lain seperti current ratio dalam rasio likuiditas, atau return on asset dalam rasio profitabilitas. Periode amatan juga dapat diperpanjang dalam penelitian lain berikutnya agar dapat diketahui adanya perubahan kinerja perusahaan secara lebih detil.

\section{REFERENSI}

Efendi, A.F.W, dan S.S.A Wibowo, 2017, Pengaruh Debt to Equity Ratio (DER) dan DebT to Asset Ratio (DAR) terhadap Kinerja Perusahaan di Sektor Keuangan yang terdaftar di Bursa Efek Indonesia, Jurnal of Applied Managerial Accounting 1(2): 157-163.

Fahmi, Irham. 2015. Pengantar Manajemen Keuangan Teori dan Soal Jawab Bandung: Alfabeta.

Fachry, Muhammad, 2016, Analisis Struktur Modal Terhadap Kinerja Perusahaan (Studi Pada Perusahaan Jasa Sektor Transportasi Yang Terdaftar di BEI 2010-2014). Skripsi Diterbitkan. Makassar: Fakultas Ekonomi dan Bisnis Universitas Hasanuddin.

Hanafi, Mamduh M. 2012. Analisis Laporan Keuangan. Edisi Ketiga.Cetakan Pertama. Yogyakarta: UUP Sekolah Tinggi Ilmu Manajemen YKPN

aryono, S.A., Fitriany, Eliza Fatima, 2017, Pengaruh Struktur Modal dan Struktur Kepemilikan terhadap Kinerja Perusahaan, Jurnal Akuntansi dan Keuangan Indonesia, 14(2): 119-141.

Ismawati, Kun, 2019, Financial Performance of Banking Industry. Jurnal Akuntansi dan Sistem Teknologi Informasi Universitas Slamet Riyadi Surakarta, 15(4): 537-550.

Kasmir. 2014. Analisis Laporan Keuangan, Ed.1. Cetakan Ketujuh. Jakarta: PT.Rajawali Pers.

Maulita, Dian dan Inta Tania, 2018, Pengaruh Debt to Equity Ratio, Debt to Asset Ratio, dan Long term Debt Asset Ratio Terhadap Profitabilitas (Studi Pada Perusahaan Manufaktur Sub Sektor Makanan dan Minuman Yang Terdaftar di BEI 2011-2016). Jurnal Akuntansi, 5(2): 132-137.

Mispiyanti, 2020, Pengaruh Struktur Modal, Capital Expenditure, Profitabilitas dan Kebijakan Dividen terhadap Nilai Perusahaan pada Perusahaan BUMN di Indonesia. Jurnal Akuntansi dan Pajak STIE-AAS Surakarta, 20(02): 133-144. 
Munawir, S. 2014. Analisis Laporan Keuangan. Yogyakarta: Liberty.

Mutia, Dewi, Syamwil, dan Abel Tasman, 2018, Pengaruh Profitabilitas, Struktur Modal dan Likuiditas Terhadap Harga Saham Perusahaan Sub Sektor Transportasi Yang Terdaftar di BEI Tahun 2012-2017, Jurnal Ecogen Universitas Negeri Padang, 1(2): 390-399.

Nasrun, Amanah Utami. 2014. Analisis Struktur Modal Dan PengaruhnyaTerhadap Kinerja Perusahaan Property Dan Real Estate Yang Terdaftar di BEI Periode 2008-2012. Skripsi Diterbitkan. Makassar: Fakultas Ekonomi dan Bisnis Universitas Hasanuddin.

Ningsih, Endang Surya. 2013. Pengaruh Struktur Modal Terhadap Kinerja Perusahaan Go Publik Yang Listing Di Bursa Efek Indonesia. Skripsi Diterbitkan. Padang: Program Sarjana UPI YPTK.

Permatasari, Diana, dan Devi Farah Azizah, 2018,

Pengaruh Struktur Modal Terhadap Nilai

Perusahaan (Studi Pada Perusahaan Sub Sektor

Makanan Dan Minuman Yang Terdaftar Di

Bursa Efek Indonesia Tahun 2013-2016), Jurnal

Administrasi Bisnis (JAB), 61(4): 100-106.

Putri, Julia, 2016, Pengaruh Struktur Modal terhadap

Nilai Perusahaan pada Perusahaan Manufaktur Go Publik (Studi Kasus Sektor Makanan da Minuman), JOM FISIP Fakultas Ilmu Sosial dan Politik Universitas Riau, 3(2): 1-12.

Riyanto, Bambang. 2010. Dasar-Dasar Pembelanjaan Perusahaan, ed.4 Yogyakarta: BPFE-Yogyakarta.
Sari, Ni Made Vironika dan I.G.A.N, Budiasih, 2014, Pengaruh Debt to Equity Ratio, Firm Size, Inventory Turnover dan Assets Turnover pada Profitabilitas, E-Jurnal Akuntansi, 6(2): 267279.

Sartono, Agus. 2010. Manajemen Keuangan Teori dan Aplikasi. Ed.4. Yogyakarta: BPFE

Setiana, Esa. dan Rahayu, Desy. 2012. Analisis Pengaruh Struktur Modal Terhadap Kinerja Pada Perusahaan Otomotif Yang Terdaftar di BEI 2008-2010. Jurnal Telaah Akuntansi. Medan: Fakultas Ekonomi dan Bisnis Universitas Negeri Medan: 13(1):33-50.

Sugiyono. 2014. Metode Penelitian Kuantitatif Kualitatif dan R\&D. Bandung: Alfabeta.

Sutrisno. 2012. Manajemen Keuangan Teori, Konsep dan Aplikasi. Yogyakarta: EKONISIA.

Syamsuddin, Lukman. 2011. Manajemen Keuangan Perusahaan. Jakarta: PT.Rajawali Pers.

Wardani, A.K dan Farida Ratna Dewi, 2015, Analisis Struktur Modal terhadap Kinerja Keuangan Perusahaan Sektor Utama yang Terdaftar di Indeks LQ45 Bursa Efek Indonesia, Jurnal Manajemen dan Organisasi, VI(2): 134-148.

https://kemenperin.go.id/artikel/18544/2017.

Diaksestanggal 02 Desember 2019. Pukul 20.00WIB.

http://bisnisbandung.com/2019/05/24. Diakses tanggal 02 Desember 2019. Pukul 20.30WIB.

http://www.idx.co.id/perusahaan-tercatat/laporan-

keuangan-dan-tahunan/, Diakses Pada tanggal 03 Desember 2019. Pukul 21.30WIB.

https://www.sahamok.com/emiten/sektor-anekaindustri/sub-sektor-tekstil-garment/, Diakses Pada tanggal 12 Desember 2019. Pukul 14.00 